\title{
General practitioners and district nurses A study of referral patterns in the City of Aberdeen
}

\author{
I. M. RICHARDSON \\ Department of General Practice, University of Aberdeen
}

\begin{abstract}
Summary
Variation between Aberdeen general practitioners in referral rates for home and surgery nursing care is shown to be substantial and is related to the proportion of elderly patients in the practice, inversely to list size, to the doctor's experience, and to practice attachment of nurses. There is, however, a large unexplained variation which, it is suggested, reflects differing general practitioner perception of nursing need and nursing skill, a situation that could be improved by joint training.
\end{abstract}

\section{INTRODUCTION}

Attachment of home (district) nurses to general practice is now widespread and is generally thought to have improved patient care, both at home and in the surgery. In fact there is still very little evidence of direct benefit to patients from attachment (Hawthorn, 1971), and apart from expressions of mutual acceptability by doctors and nurses, it is at least doubtful whether understanding of each other's roles and skills has been much enhanced. The doctor's perception of a patient's need for the services of a home nurse will depend largely on what he knows, or thinks he knows, about nursing skills. Therefore, by measuring a doctor's rate of referral of patients for home nursing and by relating this to a number of variables such as attachment, practice size and composition, and experience of the doctor, it might be possible to point epidemiologically to some of the determinants of team care.

\section{Method}

Through the good offices of Aberdeen District Nursing Association records were made available showing for the three months May, June, and July 1972, and for each general practitioner in Aberdeen, the number of new patients referred for home nursing care. In addition, for those practices with attached nurses, records were kept for the same period of all new patients referred for nursing attention in the surgery premises. These numerators were related to the doctor's practice population to give a referral rate per 1,000 patients for the period May-July 1972 (for practices with two or more doctors the denominator had to be estimated by dividing the total practice list by the number of doctor principals).

\section{RESUlTS OF 1972 STUdY}

During that summer period referral rates varied quite widely between doctors, there being only a small difference between the group of doctors with nurses attached and the group without (Table I).

TABLE I

REFERRAL RATES FOR HOME NURSING PER 1,000 PATIENTS MAY-JULY 1972

\begin{tabular}{l|c|ccc}
\hline & \multicolumn{1}{c|}{\begin{tabular}{c} 
Practice \\
\multicolumn{1}{c|}{$\begin{array}{c}\text { No. of } \\
\text { Doctors }\end{array}$}
\end{tabular}} & \multicolumn{2}{|c}{ Referral Rate } \\
\cline { 3 - 4 } $\begin{array}{l}\text { With nurses attached } \\
\text { Without nurses attached }\end{array}$ & $\ldots$ & 44 & Average & Range \\
\hline
\end{tabular}

In both groups referral rates were positively correlated with the proportion of patients aged 65 and over on the doctor's list, but only in the attached group did this achieve statistical significance. In both groups an inverse correlation was found with list size, the referral rate being $6 \cdot 3$ in practices with less than 1,800 patients per doctor, and $4 \cdot 5$ in practices larger than 2,200 patients per doctor; perhaps the most likely explanation of this trend is that the smaller the list size, the better will the doctor be able to know the nursing needs of his patients.

Referral rates for treatment by the nurse in the surgery premises were, of course, available only for practices with nurses attached. The average rate per 1,000 patients for the three-month period for 40 doctors was $26 \cdot 7$, the range stretching from $168 \cdot 1$ to 0.6 . This large variation is probably produced by several factors, but one undoubtedly is availability of a treatment room for the nurse. 
For example, in one practice with such a room the average referral rate per doctor was 110 , whereas in another practice of the same size but with no treatment room the rate was 9.8. But even within practices there was striking variation in the use of the surgery nurse, the largest being in a three-doctor practice where one partner's referral rate was 20 times greater than another partner's rate. No correlation was found between referral rates for home and surgery nursing services.

\section{THE 1973 STUdY}

The foregoing study was a trial run and its results could have been atypical in that during the summer holiday months doctors' referral habits may be modified. To check on this, and to obtain some information on reasons for referral, a second study was mounted in February, March, and April 1973; this concerned referrals for home nursing only and included the age, sex, and service requested for each patient.

TABLE II

REFERRAL RATES FOR HOME NURSING PER 1,000 PATIENTS, FEBRUARY-APRIL 1973

\begin{tabular}{|c|c|c|c|}
\hline \multirow[b]{2}{*}{ Practice } & \multirow{2}{*}{$\begin{array}{l}\text { No. of } \\
\text { Doctors }\end{array}$} & \multicolumn{2}{|c|}{ Referral Rate } \\
\hline & & Average & Range \\
\hline $\begin{array}{l}\text { With nurses attached } \\
\text { Without nurses attached }\end{array}$ & $\begin{array}{l}50 \\
39\end{array}$ & $\begin{array}{l}6 \cdot 0 \\
4 \cdot 5\end{array}$ & $\begin{array}{l}0-15 \cdot 1 \\
0-13 \cdot 5\end{array}$ \\
\hline
\end{tabular}

The discrepancy in the number of doctors between Tables I and II is due to the omission from the first study of three practices where changes of personnel made the figures quite unusual. The second set of referral rates shows a rather larger difference between average referral rates in attached and non-attached practices and a wider range of individual doctor's rates, but the pattern of the two study periods is fairly similar, there being in each a slightly higher use of home nursing services by doctors with nurses attached to their practice.

As with the 1972 data, an association was found between referral rate and the proportion of people aged 65 and over on the doctor's list, in both attached and non-attached practices (Table III).

These findings are in accord with the well-known fact that most of the domiciliary nurse's work is with elderly patients, but they also show that the higher referral rate where the nurse is practiceattached is independent of the proportion of old people. It seems likely that this greater use of
TABLE III

HOME NURSING REFERRAL RATES PER 1,000 PATIENTS BY PROPORTION OF ELDERLY PEOPLE ON DOCTOR'S LIST

\begin{tabular}{|c|c|c|c|c|}
\hline \multirow{2}{*}{\multicolumn{2}{|c|}{$\begin{array}{l}\% \text { of Elderly People } \\
\text { on Doctor's List }\end{array}$}} & \multicolumn{3}{|c|}{ Practice } \\
\hline & & Attached & $\begin{array}{c}\text { Non- } \\
\text { Attached }\end{array}$ & All \\
\hline $\begin{array}{l}21 \text { and over .. } \\
15 \text { to } 20 \\
14 \text { and less } \ldots\end{array}$ & $\begin{array}{l}\ldots \\
\cdots\end{array}$ & $\begin{array}{l}8 \cdot 7 \\
6 \cdot 5 \\
5 \cdot 6\end{array}$ & $\begin{array}{l}5 \cdot 1 \\
4 \cdot 7 \\
4 \cdot 0\end{array}$ & $\begin{array}{l}6 \cdot 9 \\
5 \cdot 5 \\
5 \cdot 0\end{array}$ \\
\hline
\end{tabular}

nursing services results from the learning that takes place when doctor and nurse (and health visitor) can meet, as they presumably do more easily in attachments.

Again a significant inverse association was found between referral rate and list size in both attached and non-attached practices (Table IV).

TABLE IV

HOME NURSING REFERRAL RATES PER 1,000 BY PRACTICE SIZE

\begin{tabular}{|c|c|c|c|}
\hline Practice Siz & & No. of Doctors & Referral Rate \\
\hline $\begin{array}{l}800-1,500 \\
1,600-2,000 \\
2,100-2,400 \\
2,500 \text { and over }\end{array}$ & $\begin{array}{l}\ddot{ } \\
\ddot{ } \\
.\end{array}$ & $\begin{array}{r}12 \\
38 \\
31 \\
3\end{array}$ & $\begin{array}{l}8 \cdot 3 \\
5 \cdot 5 \\
4 \cdot 8 \\
3 \cdot 5\end{array}$ \\
\hline
\end{tabular}

Though it seems likely that this relationship reflects the greater knowledge of patients' needs possessed by doctors with smaller lists, the situation is complicated by the fact that singlehanded doctors have smaller lists and a slightly higher proportion of elderly patients than do doctors in partnerships. It was also of interest to discover that for single-handed doctors the variance round the mean referral rate was $11 \cdot 25$, compared with 7.08 in two-doctor practices and 5.04 in four-doctor practices. It is tempting to suggest that this is evidence of partnership agreement on practice policy.

The last influence on referral rate to be examined was the length of the doctor's experience, as measured by years since graduation (obtained from the Medical Register) (Table V).

Though the limited amount of data imposed a rather crude standardization on list size and proportion of elderly patients, there is a trend in both attached and non-attached practices for older doctors to have higher referral rates than younger doctors. An explanation of this trend can be only speculative but it appears likely that experience brings not only greater medical perception of 
TABLE V

REFERRAL RATES FOR HOME NURSING PER 1,000 PATIENTS BY LIST SIZE, PROPORTION OF ELDERLY PATIENTS ON DOCTOR'S LIST, ATTACHMENT/NON-ATTACHMENT AND YEARS OF DOCTOR EXPERIENCE

\begin{tabular}{|c|c|c|c|c|c|}
\hline \multirow[b]{2}{*}{ List Size } & \multirow{2}{*}{$\begin{array}{l}\% \text { of Elderly } \\
\text { Patients }\end{array}$} & \multirow{2}{*}{$\begin{array}{l}\text { Years since } \\
\text { Graduation }\end{array}$} & \multicolumn{3}{|c|}{ Average Referral Rates } \\
\hline & & & Attached & Non-attached & All Practices \\
\hline \multirow[t]{2}{*}{1,800 and less } & 14 and less & $\begin{array}{l}21 \text { and over } \\
20 \text { and less }\end{array}$ & $\begin{array}{ll}5.9 & (5)^{*} \\
7.5 & (3)\end{array}$ & $\begin{array}{ll}7.9 & \text { (2) } \\
3.9 & \text { (2) }\end{array}$ & $\begin{array}{ll}6 \cdot 5 & (7) \\
6 \cdot 0 & (5)\end{array}$ \\
\hline & 15 and more & $\begin{array}{l}21 \text { and over } \\
20 \text { and less }\end{array}$ & $\begin{array}{ll}9 \cdot 6 & \text { (5) } \\
5 \cdot 1 & (2)\end{array}$ & $\begin{array}{ll}6 \cdot 0 & \text { (8) } \\
3 \cdot 3 & \text { (1) }\end{array}$ & $\begin{array}{ll}7 \cdot 4 & (13) \\
4 \cdot 5 & (3)\end{array}$ \\
\hline \multirow{2}{*}{1,801 and more } & 14 and less & $\begin{array}{l}21 \text { and over } \\
20 \text { and less }\end{array}$ & $\begin{array}{l}7 \cdot 3 \text { (6) } \\
4 \cdot 1 \quad \text { (11) }\end{array}$ & $\begin{array}{ll}3 \cdot 1 & (4) \\
3 \cdot 9 & (8)\end{array}$ & $\begin{array}{ll}5 \cdot 6 & (10) \\
4 \cdot 0 & (19)\end{array}$ \\
\hline & 15 and more & $\begin{array}{l}21 \text { and over } \\
20 \text { and less }\end{array}$ & $\begin{array}{ll}7 \cdot 8 & \text { (8) } \\
5 \cdot 6 & (6)\end{array}$ & $\begin{array}{ll}4 \cdot 8 & \text { (8) } \\
2 \cdot 7 & \text { (5) }\end{array}$ & $\begin{array}{l}6 \cdot 3 \quad(16) \\
4 \cdot 3 \quad(11)\end{array}$ \\
\hline
\end{tabular}

*Number of docters shown in parentheses

nursing need and skill but also a heavier case load of chronically ill patients (not necessarily older patients).

\section{REASONS FOR REFERRAL}

The nurses classified their referrals according to the service requested. The patterns of referral are shown in Table VI.

TABLE VI

REASONS FOR REFERRAL

\begin{tabular}{|c|c|c|c|c|c|c|c|}
\hline \multirow{2}{*}{\multicolumn{2}{|c|}{ Nursing Service }} & \multicolumn{3}{|c|}{$\begin{array}{l}\text { Attached } \\
\text { Practices }\end{array}$} & \multicolumn{3}{|c|}{$\begin{array}{l}\text { Non-attached } \\
\text { Practices }\end{array}$} \\
\hline & & No. & $\%$ & $\begin{array}{c}\text { Mean } \\
\text { Age }\end{array}$ & No. & $\%$ & $\begin{array}{c}\text { Mean } \\
\text { Age }\end{array}$ \\
\hline \multicolumn{2}{|c|}{ 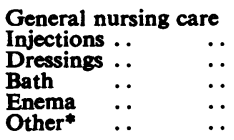 } & $\begin{array}{r}120 \\
80 \\
190 \\
53 \\
29 \\
117\end{array}$ & $\begin{array}{r}20 \\
14 \\
32 \\
9 \\
5 \\
20\end{array}$ & $\begin{array}{l}74 \\
61 \\
53 \\
72 \\
62 \\
44\end{array}$ & $\begin{array}{l}73 \\
47 \\
91 \\
28 \\
25 \\
57\end{array}$ & $\begin{array}{r}23 \\
15 \\
28 \\
9 \\
8 \\
18\end{array}$ & $\begin{array}{l}75 \\
60 \\
56 \\
75 \\
70 \\
47\end{array}$ \\
\hline Total & .. & 589 & 100 & 59 & 321 & 100 & 62 \\
\hline
\end{tabular}

*Three-quarters of this category was removal of sutures.

The similarity in distribution of the categories of nursing service in attached and non-attached practice groups is close, so it seems that the higher referral rate by doctors with nurses attached to their practices reflects, on the whole, greater use of nursing services of all kinds. But that statement conceals the fact that within both attached and nonattached practice groups wide variations were seen between individual doctors, sometimes within the same practice; for example, nearly $40 \%$ of both groups of doctors recorded no referrals at all for injections at home, and seven doctors referred no patients for dressings, whereas one doctor had 11 such referrals. From the mean ages in Table VI it can be seen that doctors with attached nurses tend to refer patients at a rather younger age than doctors without attached nurses.

Just how striking variation between two similar groups of doctors can be is shown in Table VII. Practice B had twice as many referrals for general nursing care, twice as many for dressings and suture removal, but only half as many as practice $\mathbf{A}$ for injections. The explanation of such variation can only come from further study.

\section{Discussion}

The variation among general practitioners in their referral rates for home nursing is so wide as to raise three serious questions: are the low users missing patient needs, are the high users asking too much of the service, are some doctors undertaking work which nurses do in other practices? On the last question, though the data from this study can shed no direct light, there can be little doubt that the answer is 'yes'-not all doctors wish to delegate every injection or dressing. The prior two

TABLE VII

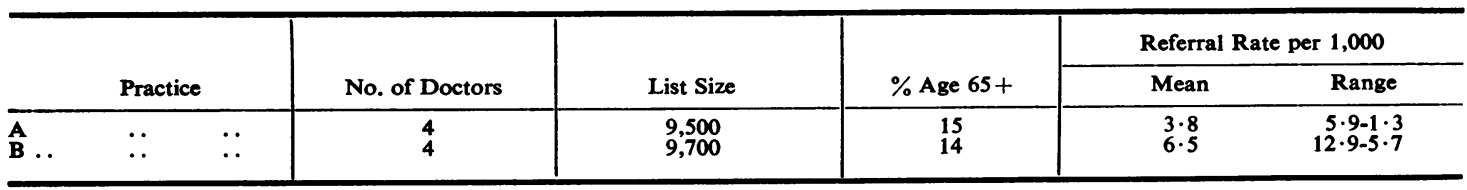


questions can be answered only when and if firm criteria for sound use of home nursing services are available. Such criteria are not explicit at the present time, yet using a simple self-care index it should be quite feasible to assess accurately the need for home nursing care, assuming, of course, that doctor and patient are in contact. The increasing use of health visitors for comprehensive assessment of the elderly patients in a practice should help to ensure that all but a very few recluses obtain necessary medical and nursing care.

But even if assessment of need were more comprehensive than it now is, how would doctors know whether they were over- or under-using the domiciliary nursing service? Simple routine measurements should be introduced forthwith so that every doctor could be shown his own usage rate of the nursing service and how he compares with the average for his area (a feed-back not unlike, though with a different purpose from, prescribing statistics for general practitioners). The provision of this information, its interpretation, and its use in practice team policy are surely a responsibility for the new integrated health service.

Similar considerations apply to the use of nursing skill in the consulting premises; there seems little point in attaching nurses to practices unless and until adequate arrangements of equipment and accommodation are made for them. But in respect of both kinds of nursing service there can be little doubt that differences in doctors' understanding of nurse skills is behind a great deal of the variation here recorded; I think it can be further argued that this is due substantially to the time and organizational pressures still operating on most general practitioners-hence this study's finding of a higher referral rate in smaller practices. Most principals in practice today will have learned through experience what they can ask of their nursing service but it does not follow that their successors, the vocational trainees of today and tomorrow, should also and only learn that way. The introduction of joint systematic demonstrationdiscussions into vocational training of both doctors and nurses would appear to be the best startingpoint for learning about each other's roles, the essential basis for perception of need by members of the community care team.

This study forms part of a larger research project being conducted in the Department of General Practice by Mrs. Jean MacIntosh, a nursing research fellow, which is supported by a grant from the Scottish Home and Health Department.

I am deeply grateful to Mrs. A. M. Taylor, Superintendent of the Aberdeen District Nursing Association, for her interest and immense help, and to all the nursing sisters who kept such admirable records for me.

\section{REFERENCE}

HAWTHORN, P. (1971). The nurse working with the general practitioner-an evaluation of research and a review of the literature. Department of Health and Social Security, London. 